\title{
ANALYTICAL STUDY ON NASR HAMID ABU ZAYD'S UNDERSTANDING OF RELIGIOUS TEXTS IN ISLAM
}

\author{
Nader Falyouna ${ }^{*}$
}

\begin{abstract}
Understanding religious texts in Islam has differed since the time of the Prophet Mohammed. After this era, two schools with different concepts were formed to handle religious texts: a school that commits to the orignal text literally regardless of contextual considerations, and another places the importance of having a reference to other contextual determinants. Thus, the jurists continued to understand the texts through what was established by the scholars of the two schools. Later, a group of scholars tried to develop a new approach to understand the texts based on non-adherence to the former curricula. They believed that Muslims were impacted by events that took place in their social life, the way they understood Islam, and the political situation that surrounded them. It was necessary to develop a new approach to meet the demands of the developments of the era, serving as a mean to get out of the decline of Muslims in light of the modern European Renaissance. The most prominent of these thinkers was Nasr Abu Zayd, who has caused a stir in public and intellectual circles in Egypt. This research paper sheds light on a range of political factors that influenced the formation of his thoughts.
\end{abstract}

Keywords: Nasr Abu Zayd, Politics, Renewal, Egypt, Islam

\section{Introduction}

Throughout the history, Muslims have experienced various circumstances affecting their social life and the way they understand Islam. The political situation was one of the major factors that cannot be overlooked when talking about this influence. One of the most prominent thinkers influenced by the political situation was Nasr Abu Zayd, whose understanding of the religious texts has been influenced by these political factors. His writings caused a stir among intellectuals and the public in Egypt, where he was forced to leave Egypt to the Netherlands in 1995 following the issuance of a decision by the Court of Appeal in Cairo, which was supported by the Supreme Court, to divorce his wife after issuing a ruling that he was no longer Muslim. ${ }^{1}$

The previous researchers who wrote about Abu Zayd's methodology in understaning the religuos texts never took into consideration the effect of the political enviroment on Abu Zayd's thoughts. They only tried to criticize his ideas without looking for the factors that led to his adoption. For example, Abu Hadi in his PhD thesis, discussed Abu Zayd's approach in interpreting the texts of Qur'an and Sunnah without mentioning the factors that influenced Abu Zayd. ${ }^{2}$ Mustafa explained the intellectual approach on which Abu Zayd relied on in the analysis and progress of the texts, and criticized his way of thinking and how he looked at the texts of the Sunnah. ${ }^{3}$ In addition, Mustafa mentioned in his paper four other articles that included responses to Abu Zeid and criticized his ideas as well, without looking to the backgrounds of his concept in understaning Qur'an and Sunnah. ${ }^{4}$ Therefore, in this research paper, the researcher sheds light on a range of political factors that influenced the formation of the religious thought of Abu Zayd.

\footnotetext{
* Nader Falyouna, Post Graduate Candidate, Social Sciences Institute, Sakarya University, Turkey. Email: nader.falyouna@ogr.sakarya.edu.tr. ORCHID: https://orcid.org/0000-0002-0581-2126.

${ }^{1}$ Kermani, Navid (2004), "From Revelation to Interpretation: Nasr Hamid Abu Zayd and the Literary Study of the Qur'an," in Modern Muslim Intellectuals and the Qur'an, London: Oxford University Press, p. 170. For more details in this matter, please refer to Abu Zayd, Nasr (1995), Thinking of the time of Calling people Not Muslims against ignorance, falsity and superstition, Cairo: Madbouli Library, pp. 265-277. In his book, Abu Zayd attached a decumentary and mentioned the divorce cliam between him and his wife.

${ }^{2}$ Abu Hadi, Ibrahim (2011), Naser Abu Zayd and his methodology in dealing with heritage, Makkah: Umm Al-Qura University, pp. 15-16.

${ }^{3}$ Mustafa, Ali (2014), "The critical doctrine of Dr. Nasr Hamed Abu Zayd and his opinion in the inference from the Sunnah," The Journal of Ilahiyat, Harran University, Vol. 19, No. 32, p. 154.

${ }^{4}$ Mustafa (2014), "The critical doctrine of Dr. Nasr Hamed Abu Zayd," p. 153.
} 


\section{The Life of Nasr Abu Zayd}

Nasr Abu Zayd was born on July 10, 1943 in Quhafa, a small village in the Nile Delta of Egypt, to a poor family. He was unable to enroll in the university at first. Therefore, he studied in one of the industrial secondary schools -the radio department- and received a technical diploma in 1960 . He worked as a technician in the telecommunications service of the Egyptian General Telecommunications Authority. He joined the Faculty of Arts at Cairo University while he was working to support himself and his family. He obtained a bachelor's degree from the Department of Arabic Language and Literature in 1972. He received a master's degree in 1976, and $\mathrm{PhD}$ in 1981 from the same university, at which he enrolled as a teaching staff ranging from an assistant professor to an associate professor. ${ }^{5}$

In May 1992, he submitted his research to obtain the title of a full professor from the Department of Arabic Language at Cairo University. ${ }^{6}$ Hence, his struggle with the university and society began. Dr. Abdul Sabour Shahin ${ }^{7}$ objected to some of the research findings by Abu Zayd which he presnted for promotion. The problem developed to be a case of public opinion and a court took a decision ruling that Abu Zayd is no longer a Muslim and that his wife should be divorced from him, forcing him to leave Egypt to the Netherlands in 1995. Since then, he became a professor of Arabic language and Islamic Studies at the University of Leiden in the Netherlands. ${ }^{8}$ On Monday, July 5, 2010, Abu Zayd passed away at a hospital in Cairo after a long fight with illness. ${ }^{9}$

\section{Nasr Abu Zayd Revolts against the Old Literature}

Nasr Abu Zayd led a rebellion against the old religious literature, calling at the same time for re-reading the religious texts in a new manner according to the standards and conditions of modern times, to serve the humanity and the Islamic community. The texts, in his view, cannot be considered as rigid templates that could only be understood through the traditional understanding of scholars and commentators, which was based on political circumstances that influenced much of their jurisprudence at that time. ${ }^{10}$

Nasr Abu Zayd's goal was to renew the academic movement in the field of Islamic studies, especially in the field of re-reading the texts again, away from the surrounding political circumstances, and not to limit it to the heritage of the first centuries that was given a sort of 'holiness' unless because knowledge is renewed and is not limited to a certain extent, but includes all energies, scholars and fields in order to understand the text based on the development and advancement reached by scholars in the current era regarding the analysis of texts, and to read the texts in a new way using critical scientific research as Nasr Abu Zayd stated: "This type of critical analytical research - deconstruction - shakes the sacred ideas that accumulated around specific events in the Islamic history and debunks other ideas that contradict with what actually happened by challenging the existing literature." 11

\section{The Influence of the Political Environment on His Renewal Discourse}

Abu Zayd lived in a period where political parties and different religious ideologies were in conflict. That period also witnessed a violent struggle between right-wing and left-wing movements. This led Nasser Abu Zayd to stand up to these events and try to come up with new ideas announcing the birth of a new intellectual renaissance. The researcher identifies the most important impact of the innovative discourse of Nasr Abu Zayd.

\section{The Prevailing of Political Conditions and the Exploitation of Religious Discourse for Personal Purposes}

Some of the phenomena that occurred during the time of Abu Zayd had a profound impact on the Egyptian street, which influenced the writings of Abu Zayd as well. Examples of this revealed the

\footnotetext{
5 Haydar, Abd As-salam (2015), “An introduction to Nasr Abu Zayd Reading," Tawaseen, retrieved 12 $2^{\text {st }}$ January 2020, http://tawaseen.com/?p=1905.

${ }^{6}$ Abu Zayd, Nasr and Nelson, Esther R. (2004), Voice of an Exile: Reflections on Islam, Westport: Praeger, p. 1.

${ }^{7}$ Dr. Abdul Sabour Shahin was a professor at the College of Dar al-Ulum in Cairo. Abu Zayd and Nelson (2004), Voice of an Exile, p. 2.

${ }^{8}$ Abu Zayd and Nelson (2004), Voice of an Exile, pp. 1-2.

9 France24 Network (2010), "The death of controversial thinker Nasr Hamid Abu Zayd," retrieved $5^{\text {th }}$ Fabruary 2020,

https://www.france24.com/ar/20100507-egypt-culture-abu-zayd-thinker-death-zayed-hospital-cairo.

${ }_{10}^{10}$ Abu Zayd, Nasr (2008), Speech and Interpretation, Casablanca: The Arab Cultural Center, p. 19.

${ }^{11}$ Abu Zayd (2008), Speech and Interpretation, p. 20.
} 
problem of financial exploitation by some Islamic groups through companies that employ Islamic funds as alternative institutions for the interest of Western banks (Al-Rayyan Group), whose owners were later lied to people and took advantage of the money of religious discourse to raise people's money and fraud. ${ }^{12}$ This speech against them was used in the statement of the sterility of religious discourse in that period, Abu Zayd says: "On the other hand, there is a distinction between the proclaimed banners of religious discourse and the practical practices of politics, economy and thought. The banners are beautiful and glamorous: Islam is the solution, the Islamic Renaissance, the Islamic Civilizational project." 13

Nasr Abu Zayd lived between July 10, 1943 and July 5, 2010. During this period, the activity of the religious groups in particular, especially in the second half of the twentieth century $\mathrm{AD}$, after the death of President Gamal Abdel Nasser in 1970, and Anwar Sadat assumed the verdict afterwards, who opened the door to the Islamic groups to spread in the Egyptian society, and the ensuing events ended with the assassination of the Egyptian President, Anwar Sadat, on October 6, 1981, which raised many questions about the role of religious discourse in violence and extremism, and how to handle these phenomena that have impacted Muslim societies in general and Egypt in particular. ${ }^{14}$

At the time, Egypt passed through what seemed to be a cultural and intellectual revolution which changed the political scene for those who lived in that period. Examples for these revolutions are the liberal revolution in 1919 against the British ${ }^{15}$, and the Free Officers revolution, with a socialist nature, against the royal rule of Egypt in 1952. ${ }^{16}$ The writings of Sayed Qutb before and in the beginning of the revolution had an impact on the revolution, which shifted towards socialism. The writings of Sayed Qutb were part of the fabric of the national discourse before shifting towards radicalism, which has paved the way for terrorism in the name of Islam in Egypt later on. ${ }^{17}$ The religious Islamic parties in that period tried to employ his writings in their favor, which required revising all those writings, which sought to reveal the seriousness of Abu Nasr and the impact of these writings on stopping the wheel of progress and renaissance. This was evident in his book Criticism of the Religious Discourse, which was the beginning of a series of crises for him and the reason behind the issuance of a rule by a court to separate between him and his wife. ${ }^{18}$

\section{Refusal of New Literature Without Constructive Criticism}

One of the things that affected Nasr Abu Zayd was that he was facing a "personal" war with his opponents, regardless of what is coming out of Abu Zayd himself; all he says or offers in their view is to keep up with the West in his social and political life and his scientific methods in understanding the texts and satisfying them in the first place without criticizing the words of Abu Zayd in scientific criticism. ${ }^{19}$ Even when Abu Zayd wanted to renew the religious discourse in his view of the overall purposes of Shari'a, the implications of Abu Zayd's war against his opponents in that period were overshadowed by his innovative discourse ${ }^{20}$, which made him write about: reason, freedom, social justice, quoting from other scholars, which made everyone circulate news of his disbelief as was decided by his rival Abdul Sabur Shaheen, without using reason to rule out that Abu Zayd was no longer a Muslim.

Using the same weapon of old heritage, courts in Egypt were used by his rivals against him through the Personal Status Law (Al-Hisba) in the Hanafi doctrine, which calls for bringing people accountable for what they do, thus his opponents launched a campaign against him, which ended with his exile from his country. Nasr Abu Zayd spoke about the legitimate objectives of Shari'a:

\footnotetext{
${ }^{12}$ Abu Zayd, Nasr (1994), Criticism of the Religious Discourse, Cairo: Sina Press, p. 21; Abu Zayd, Nasr (2010), Renewal, prohibition and interpretation, between scientific knowledge and fear of atonement, Casablanca: The Arab Cultural Center, Casablanca, p. 27. ${ }^{13}$ Abu Zayd (1994), Criticism of the Religious Discourse, p. 29.

14 Asfour, Jaber (2014), “Conflict of Religious Discourse in Egypt," retrieved 24 January 2020, http://www.ahram.org.eg/NewsQ/299142.aspx.

${ }^{15}$ Al-Rafee, Abdul Rahman (1999), The Revolution of 1919: National History of Egypt 1914-1921, Cairo: Egyptian General Organization for Book, p. 247.

${ }^{16}$ Al-Rafee, Abdul Rahman (1989), The Revolution of July 23, 1952: Our National History in sevev years 1952-1959, Cairo: Dar Al-Ma'aref, p. 28 .

${ }_{17}$ Abu Zayd, Nasr (2004), Islamic Left: General View, Palestine: Ibrahim Abu Lughod Institute for International Studies, p. 54.

${ }^{18}$ Harb, Ali (2005), Criticism of the Text, Casablanca: Arab Cultural Center, pp. 200-201.

19 For example, see Awad, Ibraheem (2010), "Nasr Abu Zayd Mistakes and Fallacies," retrieved 9 $9^{\text {th }}$ February 2020, https://vb.tafsir.net/tafsir21285/; Amara, Muhammed (2002), Marxist interpretation of Islam, Cairo: Dar Al-Shuruk, p. 62.

${ }^{20}$ Abu Zayd (2010), Renewal, prohibition and interpretation, p. 36.
} 
We should expand the concept of reason and it should not only mean constraint but rather freedom which is a rooted concept in the Islamic tradition. If we add justice to the concepts of reason and freedom, they can be regarded as new total objectives of the Islamic project, and here we go beyond the total intentions introduced by Shatby centuries ago. But this requires a secular reading not only for the texts but for the social history of Muslims and the reality in which this battle takes place. ${ }^{21}$

Abu Zayd's reaction to his rivals' fierce campaign against him was clear. He wanted to emphasize the concept of freedom as one of the purposes of Shari'a, which must be protected and preserved so as to allow the mind to leap in the understanding of Islamic history in general and to deal with its heritage, away from the authority of the religious texts. ${ }^{22}$ During the time of the life of Abu Zayd, there was a clear tendency towards a blind tradition that considered the words of the Sheikhs on religious platforms and mosques as sacred without a review of them, and without even just giving the chance to the mind to criticize what is raised with the public.

All this without neglecting the goal of social justice that protects the society from the clutches of capitalism and feudalism, which prevailed in Egypt during the period of monarchy in the first half of the $20^{\text {th }}$ century, which influenced many scholars in that period before the revolution of the Free Officers on the $23^{\text {rd }}$ of July 1952 against King Farouk I, which overthrew the monarchy and brought socialism as an alternative to feudalism that prevailed in the past. ${ }^{23} \mathrm{Abu}$ Zayd believes that limiting the purposes of the Shari'a to punishments against theft and drinking alcohol, and the insistence of Islamist groups on the application of these punishments as a protector of the purposes of Shari'a as suggested by Shatiby ${ }^{24}$ is an ignorance of the reality of the nation in which these groups live, the lack of understanding of the Qur'anic texts and the ignorance of the purposes of sharia and the objectives of revelation in legislating these punishments. ${ }^{25}$

\section{The Setback of the Arab and Islamic Nations Following the Defeat of the 1967 War}

One factor that had an impact on the thought of Abu Zayd and his writings was the suffering of the Arab and Islamic nations from several crises and complications at all levels: social, political, economic, cultural and intellectual. ${ }^{26}$ Abu Zayd described what he had gone throught as a motivation behind starting the renewal of understanding the religious texts and discourse: "We are now, and for a while, living in a state of crisis, characterized by the weakness of the resistance of the community where the socitey lives a sort of stagnation, only recalling the achievements and victories of the past.,27

The unexpected defeat of the Arab states in the 1967 War had the greatest impact on Abu Zayd, which revealed the falsity of Arab forces, both at the religious and political levels, and thier cliam that the victory is inevitable, and it is just a matter a time. Following the sudden defeat, various attemps to interpret the reasons of defeat began to appear on the surface. One of the these interpretations was that the religious reasons are behind the defeat of Arabs in the war where Jews who adhered to the teachings of the Torah deserved victory, while Muslims who abandoned their religion and looked like the West in their lifestyle and became secular were entitled to punishment. At this time, the religious discourse tried to use it's backward methods of deception, illusions and myths in an attempt to convince people of the causes of defeat that took place against the Arab nation without looking at the real causes of weakness. "And in light of these myths to falsify people's awareness of the actual reasons for the defeat, it was necessary to address some of the writings of this interpretation, and hence the need to re-examine what was considered intellectual and doctrinal principles that guided that discourse," Abu Zayd noted. ${ }^{28}$

\footnotetext{
${ }^{21}$ Abu Zayd (1994), Criticism of the Religious Discourse, p. 44.

${ }^{22}$ Harb, Ali (2005), After the disassembly, I read like this, Beirut: Arab Institute for Studies and Publishing, p. 183.

${ }^{23}$ Al-Rafee (1989), The Revolution of July 23, 1952, p. 25.

${ }^{24}$ These necessities are religion, soul, offspring, money and mind. Shatiby, Ibraheem bin Mousa (1997), Approaches, Vol. 1, Saudi Arabia: Dar Ibn Affan, p. 31.

${ }^{25}$ Abu Zayd, Nasr (1990), The concept of text, study in the sciences of the Qur'an, Cairo: The Egyptian General Book Authority, p. 17.

26 Mady, Abu Al-Ola (2019), "The Arab Popular Situation Between the War of 67 and Today," retrieved 21" January 2020, https://www.aljazeera.net/specialfiles/pages/c2098c73-7ef8-4835-965d-25534a8a37c6\#2.

${ }^{27}$ Abu Zayd (2010), Renewal, prohibition and interpretation, p. 22.

${ }^{28}$ Abu Zayd (2010), Renewal, prohibition and interpretation, p. 23.
} 
This defeat revealed a deep flaw in the structure of the Arab and Islamic societies, some of which thought that the Arab societies entered 'modernity' from its widest gates, and that they abandoned the 'blind' tradition. Yet, what happned under the regimes of political dictatorship was the complete opposite of this. These regimes worked hard to cement the concept of obedience in the minds of Arab societies, using it as a tool in its hands such as the religious establishment was, supported by its traditional religious discourse. ${ }^{29}$ Abu Zayd describes the repercussions of the 1967 defeat:

The psychological impact of the defeat of June 1967 in Arab and Muslim consciousness can be compared to the effect of the abolition of the Caliphate: defeat has shown the state of disintegration, backwardness and loss in the structure of Arab societies. But because the defeat occurred at the hands of the army of the State of Israel, it was considered a religious defeat, classfiying the Arab-Israeli conflict as a conflict between Islam and Judaism. Since it was impossible to hold religion responsbile for the guilt of defeat, it was easy to hold Muslims responsbile for it. ${ }^{30}$

Abu Zayd believes that the reason for the defeat was not because of the Muslim's alienation from their religion, but because of the domination of the religious and political authorities of the public sphere of that period and their struggle to spread influence over the society, which was still greatly influenced by blindly imitating the religious institution and absolute obediene of the political authorities. Moreover, he has linked reactionary thought in Arab culture to military control of the state and society. ${ }^{31}$

\section{Texts and Their Historical Context in the Revolutionary Discourse of Abu Zayd}

Abu Zayd believes that old notions are given a halo of sanctity by their owners, so they could disqualify those who try to search and criticize them. Anyone who attempts to do so will be accused of being infidel using this accusation as a bomb that might explode in face of those who approach these old ideas at any time. The task of critical and analytical research is to re-think about these ideas and to take off bomb-tricker of holiness and to return these ideas to their original context as a historical human product. ${ }^{32}$

Therefore, relying on the removal of the aura of sanctity from the texts, by returning them to their historical context, guarantees the mind a wide space in its journey of seeking meanings of those texts by including in other elements in the historical understanding of what serves the interests of people in accordance with the interests of society in which they live. This approach shouuld replace another approach based on the separation of texts from the reality of people, using texts as templates produced at a certain time to address certain issues, trying to make them fit for all issues of the society in modern times, without looking at how these issues were addressed and thus resulting in the texts we have now. ${ }^{33}$

Talking about the historical process during our time is an urgent need in the eyes of Abu Zayd; to keep abreast of the development of knowledge and culture in the world, a term that requires us to possess the tools of knowledge and analysis of the text, for the production of free knowledge that does not abide by the conditions or restrictions found in the traditional books and texts. People gave these tools too much stability to the extent they made them separate from the experienced reality, as explained by Nasr Abu Zayd. This historical process is a concept that does not always mean current "but it means that we are obliged to restore the historical context of the Qur'an in order to understand the knowledge and the prospects of significance; we can distinguish judgments and legislations in a way that was not noticed by our ancestors." 34

Thus, Abu Zayd sees the nature of the relationship between religion and society as a reciprocal relationship. While religion is addressing some problems of the society under specific historical and cultural conditions, we see that under these circumstances, other circumstances can formulate another understanding of the text and its true religious framework. Limiting the relationship between religion and society on the claim that the texts of religion are fixed for all times and places, making it a must to

\footnotetext{
${ }^{29}$ Abu Zayd (2010), Renewal, prohibition and interpretation, p. 26.

${ }^{30}$ Abu Zayd (2008), Speech and Interpretation, p. 21.

${ }^{31}$ Harb (2005), Criticism of the Text, p. 213.

${ }^{32}$ Harb (2005), Criticism of the Text, p. 21.

${ }^{33}$ Amara (2002), Marxist interpretation of Islam, p. 64.

${ }^{34}$ Abu Zayd, Nasr (2004), Circles of fear: reading in the speech of women, Casablanca: The Arab Cultural Center, p. 11.
} 
apply them to any community, makes the society a negative factor in this equation. Abu Zayd noted that "Because the problematic relationship between religion and society has been reduced to a mechanical relationship in which religion plays the role of doer and the society is passive, interpretation and counter-interpretation is the foundation for these discourses." 35

Giving the language of texts an eternal status and not subjecting it to historical analysis, by ignoring its historical context and the conditions they have dealt with, and using these same solutions over the years, regardless of the environment in which we wish to address the problems, is the mistake comitted by the people who had religious power, whether it was deliberate or unintentional, says Abu Zayd.

From a philosophical and theological perspective, the divine act in history and the divine act outside it must be distinguished. The divine act in history is a historical act that is subject to historical analysis, and so is the revelation, the divine speech and the Quran. The pursuit of the text to transform the momentary and the historical into permanent, eternal and constant is part of the structure of the language in general, and one of the most important mechanisms of religious language in particular. But this sublimation does not negate the importance of historical examination of religious indications. ${ }^{36}$

The neglect of the historical context of the texts, and the placement of them in solid forms, is what led the Muslims to the political weakness and subordination, according to Abu Zayd. Therefore, it was necessary for researchers to renew the traditional religious discourse. He only called for a review of the legacy of the old discourse to produce a new one that is in line with the modern issues of the society and its concerns: "The researcher's quest to produce a scientific awareness of religion and a rational interpretation of its texts, including history and the interests of human beings as an essential element, is the danger that religious discourse feels. ${ }^{37}$

Therefore, in his most important writings, he emphasized the importance of reading and understanding texts in the light of contemporary time, and the mechanisms of contemporary textual analysis that correspond to the progress achieved by human in the mechanism of understanding texts. He believes that the linguistic aspect of the text as being productive as opposed to unproductive, which is the mistake of the traditional religious discourse. He adds that: "Reading heritage and interpreting it in the light of the problems of the current reality and its concerns represents one of the philosophical concerns in contemporary human thought." $" 38$

Abu Zayd believes that the problem is not the result of his time, but an old problem that began since the distinction between the so-called interpretation by the word, which was respected and appreciated by the people of Sunnah, and what was called interpretation by opinion, with the later being adopted by Sufis and Mutazilah, to the extent of burning books and accusing Muslims of infidelity. ${ }^{39}$ The advocates of the second school, interpretation by opinion, tried to find harmony and balance between religious meanings and mental meanings, which was opposed by jurists and narration people. He adds: "Suffice it to say that the people of Hadith and scholars were generally reluctant to go deeper into the secrets of the Qur'anic text." 40

The enmity has reached an extent where conflicting parties used political power in various times to eliminate the thought of the opposing party or at least limit its spread. Abu Zayd comments on the famous historical incident known as the Fitnah of the Creation of the Qur'an, which happened during the time of the Muslim Calip Al-Mamoun, that was provoked by Abdullah bin Abi Duaad, by saying: "The disagreement was about perceptions, not about founding creed issues, and there is a difference between perception and phenomenon. Perception is produced by people at a particular moment of the phenomenon. Social sciences, to which discourse analysis belongs, examines perceptions and analyzes people's concepts."

\footnotetext{
${ }^{35}$ Abu Zayd (2008), Speech and Interpretation, p. 12.

${ }^{36}$ Abu Zayd (1994), Criticism of the Religious Discourse, p. 43.

${ }^{37}$ Abu Zayd (1994), Criticism of the Religious Discourse, p. 48.

${ }^{38}$ Abu Zayd (2008), Speech and Interpretation, p. 173.

${ }^{39}$ Abu Zayd, Nasr (2005), Problems of reading and mechanisms of interpretation, Casablanca: The Arab Cultural Center, p. 15.

${ }^{40}$ Abu Zayd (2008), Speech and Interpretation, p. 182.

${ }^{41}$ Abu Zayd (1994), Criticism of the Religious Discourse, p. 49.
} 
Why the Historical Context?

Talking about the historical context by Nasr Abu Zayd in most of his writings was not to please the public, but rather to provide a comprehensive understanding of old texts regardless of what this old text was, especially Quraan and the narration of the Prophet of Islam. Abu Zayd comments on this by saying: "The problems of reading these texts is not limited to exploring the implcations of these texts within their cultural and historical context, but rather it was an attempt to understand the message behind every text in our modern times, at any given field of knowledge." $\$ 42$

Qur'anic or prophetic texts are ultimately 'texts' as seen by Abu Zayd, and dealing with them as if they can't be interpreted except by the first generation of Muslims and the early generation of the companions and followers, limiting this process of interpretation to them only, and permitting understanding these texts according to the first generation of Muslims is a continuation of the hegemony of political and religious authority and backwardness over those texts, which gives these changing understanding of texts the fixed character of sanctity. In order to remove this understanding from some of the statements, Abu Zayd and his companions fought, and he eventually had to leave Egypt as a result speaking of this, he said: "All interpretaions have an equal footing, and none of them has the right to claim possession of the truth, because when it does so, it rules out itself as false." ${ }^{, 3}$ The battle of the liberals who tried to spread the scientific consciousness of heritage against repressive reactionary thinking, as Abu Zayd describes, is a lost battle, "because its reliance on heritage is based on a long history of retroactive control over the heritage itself." ${ }^{44}$

The texts that dealt with the problems of the first centuries can not continue to be used to understand texts that same way today, but the jurist or the world should proceed to understand the text in a manner appropriate to the problems of its time, which emphasizes the universality of the law and its validity for all time and places, especially since the Qur'anic text in particular is the axis of Arab-Islamic culture, as Abu Zayd describes it. "the text, when it is the center of civilization or culture, must have multiple interpretations. $" 45$ This battle, which Abu Zayd fought against traditional religious discourse that tried to cut the wings of the Enlightenment intellectuals was a fierce battle in light of the facts of that time, the tools used by the advocates of the traditional discourse by all means that would tilt the balance in their favor, even if this led to antagonizing authorities, including judicial, political and popular in order to win the battle even in the short-term. ${ }^{46}$ Abu Zayd described this battle: "It is not a battle over reading or interpreting religious texts, but rather a comprehensive battle that takes place at all social, economic and political levels: a battle fought by the forces of myth in the name of religion and those who adhere to the literal meaning of religious texts.

Abu Zayd criticizes the Salafist School for understanding the texts in a way that deprives it of any historical context. This understanding, in its essence, denies, without realization, the purposes of revelation and the objectives of Shari'a by separating the text from reality by demanding the application of an absolute text to a reality." $" 48$ It is imperative to commit to the same circumstances experienced by the first generation of Muslims to apply the text to it. We have gone beyond this, as the wheel of time does not turn backwards. If we do not follow the development of our time, and understand the religious texts based on the developments of this era, we will lose control of things, and the society will go in one of three directions; either to reject developments of our time under the pretext of not having these developments in the old texts; the socitey will not be exposed to these developments, and thus the Muslim nation will remain in limboo and behind the developed nations; or to leave texts and religion and deal with emerging issues in the Islamic community, regardless of the provisions contained in these texts even if they approve or reject the developments of our time. This makes the Muslim nation loses the link with its heritage or try to combine the new with the old using a style close to the former two approaches. ${ }^{49}$

\footnotetext{
42 Abu Zayd (2005), Problems of reading and mechanisms of interpretation, p. 6.

${ }^{43}$ Abu Zayd, Nasr (1995), Text, power, truth, religious thought between the will of knowledge and the will of hegemony, Casablanca: The Arab Cultural Center, p. 8 .

${ }^{44}$ Abu Zayd (1990), The concept of text, study in the sciences of the Qur'an, p. 12.

${ }^{45}$ Abu Zayd (1990), The concept of text, study in the sciences of the Qur'an, p. 11.

${ }^{46}$ Harb (2005), Criticism of the Text, p. 205.

${ }^{47}$ Abu Zayd (1994), Criticism of the Religious Discourse, p. 63.

${ }^{48}$ Abu Zayd (1990), The concept of text, study in the sciences of the Qur'an, p. 18.

${ }^{49}$ Abu Zayd spoke about three trends for the treatment of heritage. The Salafi trend, breaking with heritage trend and renewal of the heritage trend which reconciles heritage and time. Abu Zayd (2004), Circles of fear: reading in the speech of women, pp. $190-191$.
} 
Speaking of the historical principle of understanding the texts in their proper context is an urgent need as suggested by Abu Zayd, in order not to sever the link between the Muslim nation and its heritage, to achieve the desired progress and get out of the current crises, Abu Zayd says in this regard: "If we can not ignore this legacy, we can not accept it as it is, we must redraft it. We will reject what is inappropriate for our time, affirm the positive aspects, renew it and formulate it in a language appropriate to our time. ${ }^{, 50}$ No one can claim, as Abu Zayd put it, to reach the meaning that God wanted from his words in those Qur'anic texts, which Abu Zayd calls "the objective meaning" of the Qur'anic text. Nasr Abu Zayd says: "How can we reach the objective meaning of the Qur'anic text, keeping in mind the human capacity and its limitations and lack of access to the divine, which is perfect unlike our undertanding of texts and its coverage?"51

It is worth mentioning that one of the issues that raised a lot of controversy about Abu Zayd was his understanding of some Qur'anic texts, for example: He claimed that the holy Quran is not in The Preserved Tablet, claiming there is no text that says so, and when someone objected by saying "In The Preserved Tablet," 52 his response was as follows: the saying of Allah in the Qur'an: "Rather it is a glorious Quran in a preserved tablet" does not necessarily mean the literal meaning of Tablet. There is a possibility that is more compatible with the mental approach of Islam that is the metaphorical interpretation of Tablet, the throne. "And the disagreement about that is not a disagreement about the doctrine, but a difference in perceptions. $" 53$

It is possible here to present two examples of the attempt to reach the mindset of Abu Zayd's thinking in understanding the Qur'anic text within its historical context and the circumstances surrounding it:

\section{Polygamy in Its Historical Context}

Allah says in his holy book, speaking of orphans: "If you fear that you may not deal justly with the orphans, then marry [other] women that you like, two, three, or four. But if you fear that you may not treat them fairly, then [marry only] one, or [marry from among] your slave-women. That makes it likelier that you will not be unfair." ${ }^{, 54}$ Abu Zayd tells that he met with some Sheikhs during his visit to the Higher Institute of Jurisprudence in Situbondo, east of the island of Java in Indonesia, where they discussed some issues, including the issue of polygamy referred to in the previous verse. These Sheikhs understood it according to its historical context without relying on the traditional understanding. Abu Zayd quoted this story, conveying their opinion on this issue which he agreed with. "These traditional sheikhs I have met did not see polygamy as an Islamic law, but rather as a non-Islamic tradition, which belongs to a pre-Islamic tradition, but Islam has used it to solve the problem of orphans in order to achieve justice for them." 55

Therefore, understanding the verse of polygamy outside its framework and historical context and outside its cultural bounderies does not lead to the correct understanding of it, according to Abu Zayd. The verse talks about the issue of orphans of girls, who were mistreated at that time. Al-Wahidi narrated from 'Aa'ishah that she said regarding the reason for the revelation of the previous verse: "It was revealed of a man who had an orphan who was rich, but had no one to protect an defend her. So, the verse was revealed to make sure that this man does not marry her off for money, nor does he mistreat her." ${ }^{\circ 6}$ The fact that the verse was revealed to deal with an issue that existed at that time indicates that it is not a matter of permanent legislation, but a temporary one to address an urgent issue, and dissemination of rule of polygamy even after the problem was solved is a misinterpretation of the text. ${ }^{57}$

\section{Jizya and Its Historical and Political Context}

Allah says in his holy book "Fight those who do not have faith in Allah nor [believe] in the Last Day, nor forbid what Allah and His Apostle have forbidden, nor practise the true religion, from among those who were given the Book, until they pay the tribute out of hand, degraded." 58 Abu Zayd believes that the order of Jizya is an explicit Qur'anic decree that was applied in Islamic societies, but Muslims do

\footnotetext{
${ }^{50}$ Abu Zayd (1990), The concept of text, study in the sciences of the Qur'an, p. 18

${ }^{51}$ Abu Zayd (2005), Problems of reading and mechanisms of interpretation, p. 15.

${ }_{52}$ The Holy Qur'an, Chapter 30, Surah Al- Buruj, Verse 22.

${ }^{53}$ Abu Zayd (1994), Criticism of the Religious Discourse, p. 50.

${ }^{54}$ The Holy Qur'an, Chapter 5, Surah An-Nisa, Verse 3.

${ }^{55}$ Abu Zayd (2010), Renewal, prohibition and interpretation, p. 52.

${ }^{56}$ Al-Wahidi, Ali bin Ahmed (1992), Reasons for Revelation, Dammam: Dar Al-Islah, pp. 142-143.

${ }^{57}$ Abu Zayd (2004), Circles of fear: reading in the speech of women, p. 217.

${ }^{58}$ The Holy Qur'an, Chapter 11, Surah At-Tawbah, Verse 29.
} 
not have to implement it today. Abu Zayd explains this: "Because it was appropriate for the era in which it was revealed and for the periods that followed, especially as Jizya in its essence was not an Islamic order; it was a follow-up to a firm tradition in international relations, where the defeated peoples paid the invaders protection money for each person. But the evolution of nature human relations and the structure of societies led to the adoption of citizenship rather than religion as the basis of the human community and made 'equality' among citizens the basis of the social contract." 59

This is done through the treatment of Qur'anic and prophetic texts like other literary texts. The Qur'anic text must be taught as a text ${ }^{60}$; this is based on the methods of discourse analysis. A text when it comes out to the public becomes outside the authority of the author and writer and remains in the realm of literary criticism understanding. ${ }^{61}$ It is not possible to limit the right of a critic to say an opinion at the expense of another critic, which is due to the fact that the interpretation of the Quran by the companions who the text was revealed to, is different from the understanding of someone who came after them, living different social and intellectual conditions. There is nothing to prevent the understanding of a text in a manner and tools that were not available at that time according to the social and intellectual circumstances in which we live. The understanding of the first generation of Muslims of the Qur'anic text is not sacred and can not force all people to adopt that understanding, which does not fit with the conditions of the people and their lives. Abu Zayd, speaking of the texts, says: "The real dilemma is that each critic claims to interpret the text using the only correct explanation, and that his critical doctrine is the best one to find the bjective meaning of the text as intended by its author." ${ }^{\prime 2}$

The work on the development of the elements of text analysis, is not limited to the linguistic aspect, but it includes the cultural, social, historical and intellectual ones, through which one can own the tools that enable us to understand the text in proportion to the historical era in which we live. The longer the time the text was revealed, the greater the error in its interpretation and understanding could be." ${ }^{63}$ Hence, the need to establish an approach based on scientific rules to reduce the percentage of error that can happen when understanding the texts or interpreting them.

Abu Zayd misunderstood the Qur'anic text and Sunnah as a result of the political situation in his time. Although, he tried his best to correctly understand these texts, his way of thinking was wrong. For example, based on what it was established by Sunnah, pologomy is a public legeslation and it is not a solution for a particular issue such as orphans. ${ }^{64}$ Another example is Jizya, Abu Zayd did not provide any evidance to support his idea, although it was confirmed by Quran and Sunnah and the Muslims followed this rule even after the Prophetic era. ${ }^{65}$

\section{Conclusion}

Abu Zayd lived in a period of conflict between different political parties and religious trends, which led him to confront them. Abu Zayd's philisohpy was to reject all 'old' and to re-read the texts in 'a new' manner according to the developments of modern times. Abu Zayd believes that talking about the 'historical' of our time is an urgent need to understand the texts correctly for the sake of free epistemological production, which does not comply with the conditions or restrictions we found in the heritage texts, accompanied by a number of social and political factors. Nasr Abu Zayd was met with a warring group of scholars who opposed whatever he said as he tried to introduce a new discourse without looking at what the old ideas were about, criticizing them in constructive manner. Everything he said or presented was seen by these scholars as a match for the West in its social and political life. Abu Zayd believed that the problem of challenging offending thoughts is not his problem, but rather an old one. His enemies reached a point where some of them used there political power in various forms to eliminate his thought or at least limit its spread. The defeat of the Arab states in the 1967 War was the greatest impact on Abu Zayd, who believed that it revealed the falseness of the Arab political forces in their attempt to convince people of fake reasons for the defeat of the Arab nation, without looking at the true reasons behind the defeat.

\footnotetext{
${ }^{59}$ Abu Zayd (2004), Circles of fear: reading in the speech of women, p. 10.

${ }^{60}$ Abu Zayd (1990), The concept of text, study in the sciences of the Qur'an, p. 22.

${ }^{61}$ Abu Zayd (2005), Problems of reading and mechanisms of interpretation, p. 19.

${ }^{62}$ Abu Zayd (2005), Problems of reading and mechanisms of interpretation, p. 16.

${ }^{63} \mathrm{Abu}$ Zayd (2005), Problems of reading and mechanisms of interpretation, p. 20.

${ }^{64}$ Al-Attar, Abdel Nasser (1988), Pologomy in sharia law, Asyut: Al-Muhtadeen library, p. 46.

${ }^{65}$ Ibn Qayyim al-Jawziyyah, Muhammed bin Abi Bakr (1997), Ahkām ahl al-dhimmah, Dammam: Ramadi for publication, pp. 79-80.
} 


\section{References}

Abu Zayd, Nasr (2004), Circles of fear: reading in the speech of women, Casablanca: The Arab Cultural Center.

(1994), Criticism of the Religious Discourse, Cairo: Sina Press.

\section{Studies.}

(2004), Islamic Left: General View, Palestine: Ibrahim Abu Lughod Institute for International Cultural Center.

(2005), Problems of reading and mechanisms of interpretation, Casablanca: The Arab

(2010), Renewal, prohibition and interpretation, between scientific knowledge and fear of atonement, Casablanca: The Arab Cultural Center.

(2008), Speech and Interpretation, Casablanca: The Arab Cultural Center.

(1995), Text, power, truth, religious thought between the will of knowledge and the will of hegemony, Casablanca: The Arab Cultural Center.

Book Authority.

(1990), The concept of text, study in the sciences of the Quran, Cairo: The Egyptian General

(1995), Thinking of the time of Calling people Not Muslims against ignorance, falsity and superstition, Cairo: Madbouli Library.

Abu Zayd, Nasr and Nelson, Esther R. (2004), Voice of an Exile: Reflections on Islam, Westport: Praeger.

Abu Hadi, Ibrahim (2011), Naser Abu Zayd and his methodology in dealing with heritage, Makkah: Umm Al-Qura University.

Al-Attar, Abdel Nasser (1988), Pologomy in sharia law, Asyut: Al-Muhtadeen Library.

Al-Rafee, Abdul Rahman (1999), The Revolution of 1919: National History of Egypt 1914-1921, Cairo: Egyptian General Organization for Book.

(1989), The Revolution of July 23, 1952: Our National History in Seven Years 1952-1959, Cairo: Dar Al-Ma'aref.

Al-Wahidi, Ali bin Ahmed (1992), Reasons for Revelation, Dammam: Dar Al-Islah.

Amara, Muhammed (2002), Marxist interpretation of Islam, Cairo: Dar Al-Shuruk.

Asfour, Jaber (2014), “Conflict of Religious Discourse in Egypt," retrieved 24 ${ }^{\text {th }}$ January 2020, http://www.ahram.org.eg/NewsQ/299142.aspx.

Awad, Ibraheem (2010), "Nasr Abu Zayd Mistakes and Fallacies," retrieved $9^{\text {th }}$ February 2020, https://vb.tafsir.net/tafsir21285/.

France24 Network (2010), "The death of controversial thinker Nasr Hamid Abu Zayd," retrieved $5^{\text {th }}$ February 2020, https://www.france24.com/ar/20100507-egypt-culture-abu-zayd-thinker-death-zayedhospital-cairo.

Harb, Ali (2005), After the disassembly, I read like this, Beirut: Arab Institute for Studies and Publishing. 
Harb, Ali (2005), Criticism of the Text, Casablanca: Arab Cultural Center.

Haydar, Abd As-salam (2015), “An Introduction to Nasr Abu Zayd Reading," retrieved $12^{\text {th }}$ January 2020, http://tawaseen.com/?p=1905.

Ibn Qayyim al-Jawziyyah, Muhammed bin Abi Bakr (1997), Ahkām ahl al-dhimmah, Dammam: Ramadi for publication.

Kermani, Navid (2004), "From Revelation to Interpretation: Nasr Hamid Abu Zayd and the Literary Study of the Quran," in Modern Muslim Intellectuals and the Quran, London: Oxford University Press.

Mady, Abu Al-Ola (2019), "The Arab Popular Situation Between the War of 67 and Today," retrieved $21^{\text {st }} \quad$ January 2020, https://www.aljazeera.net/specialfiles/pages/c2098c73-7ef8-4835-965d$25534 \mathrm{a} 8 \mathrm{a} 37 \mathrm{c} 6 \# 2$.

Mustafa, Ali (2014), "The critical doctrine of Dr. Nasr Hamed Abu Zayd and his opinion in the inference from the Sunnah," The Journal of Ilahiyat, Harran University, Vol. 19, No. 32.

Shatiby, Ibraheem bin Mousa (1997), Approaches, Saudi Arabia: Dar Ibn Affan. 
Journal of Al-Tamaddun, Vol. 15 (2), 2020, 45-55 